\title{
The Audio-Visual Teaching Plan for College-Level Specialty-Oriented Career Planning Courses ${ }^{*}$
}

\author{
Huiling Peng \\ National Taipei University of Business (NTUB), Taipei, Taiwan
}

\begin{abstract}
Today's career counselors for higher education need to focus on the "specialty-oriented career planning" of various departments to provide an adequate supply of professional talent for the job market. The ten specialty-oriented career planning core topics and supplemented with eight career planning relevant topics compiled into a "teaching plan" along with their corresponding audio-visual PowerPoint files are to promote the importance of college specialty-oriented career planning. This set of courses designed from the student's point of view, with a reduction in theory, while substituting such with what are "easy to read, understand, and apply" content. This set of courses has been uploaded to YouTube's "TYS Career Soft Power" playlist and can be used for flipped classroom curriculum or integrated into general education courses and professional courses. A good teaching plan and well-rounded teaching enthusiasm must accompany the "specialty-oriented career planning course" in the higher learning institutions. The department of any college/university that implements the curriculum of a specialty-oriented career-planning course might be able to make feasible and applicable arrangements within the combined planning and implementation of instruction content, including: a range of teaching objectives, teacher specifications, schedule arrangements, and teaching procedures, to realize the teaching objectives of this pilot program. The research results may serve as a reference for improving the application of curriculum planning for "specialty-oriented career planning classes and group counseling for any department" in higher education, thus, achieving the goal of promoting the model of "specialty-oriented career counseling" in colleges.
\end{abstract}

Keywords: college students, career development, specialty-oriented career planning, teaching plan

\section{Introduction}

Since the 20th century, subjects of general education have become compulsory in Europe and the United States. Career planning in general education can be a requirement for all undergraduates in higher education. In the 21st century, the development trend of career counseling/education should be geared towards preventive strategies rather than remedial education. There are two strategies that career counseling/coaching staffs usually adopt for guidance and counseling: One is a preventive strategy, and the other is a remedial strategy, attacking problems that have already occurred. The two career education strategies took from two different perspectives: facing and solving the problems as they happened, or treating the occurrence of problems as an opportunity for learning.

\footnotetext{
*Acknowledgement: Special thanks to Yi-Ning Chu who helped to record the 18 topics of the "TYS Career Soft Power" (Master Student/Institute of Information and Decision Sciences National Taipei University of Business).

Huiling Peng, Dr., professor, Department of Finance, National Taipei University of Business (NTUB).
} 


\section{Literature Review}

In Taiwan, career planning is a very popular concept. However, whether the fashionable concept has anything to do with the effectiveness of an individual's career planning is a question worth exploring. In the "2016 Global Talent Shortage Survey", conducted by Manpower Group, in which, 42,000 employers, covering 43 nations and regions, including 1,005 Taiwanese employers, were surveyed. The results show that as high as $73 \%$ of employers in Taiwan are facing difficulty in finding talent, this ranks as the second highest in the world. Compared to the results of last year, there is an increase of $16 \%$ points for Taiwan, making it the highest yearly increase since joining the survey in 2006.

In the top ten positions of talent shortage listed for Taiwan, sales representatives, engineers, and technicians are still ranked as the top three. Other positions, such as R \& D staff and management staff, are still in the top rankings, showing that the talent shortage issues in Taiwan have not significantly improved. Since 2009, the phenomenon of global talent shortage worsens every year. The talent shortage challenge in Taiwan has expanded drastically in the last two years, mainly due to rapid changes in the industry trends that offset the usual pace of talent cultivation and the supplying speed.

Additionally, more than half of the employers in Taiwan said that the reasons for professional people shortage are: (1) lack of available applicants or no applicants $(53 \%)$; (2) other reasons include: lack of experience (10\%); (3) corporate factors $(10 \%)$; and (4) lack of hard skills required in the workplace (10\%). Therefore, every college department should help college students with specialty-oriented career planning early in their studies to improve their professional employability and to increase the specialty employment rate at the time of graduation (Peng, 2015).

In recent years, there has been a serious talent shortage problem in Taiwan. Institutions of higher education should pay more attention to the specialty-oriented career planning courses in each department. According to the World Talents Report 2014, released by the International Institute for Management Development (IMD) in Lausanne, Switzerland, Taiwan ranked 27th, among 60 nations surveyed by IMD, in the "investment and development talent" factor, trailing behind Malaysia, Singapore, Hong Kong, and Indonesia, and ranked 25th in the "talent readiness — skilled labor is readily available" factor. These findings suggest that every department in today's higher education institutions should focus on "specialty-oriented career planning" to inspire freshmen's professional talent as early as possible. Many first-year students confronted with specialty indecision, rather than undecided confusion, in the realm of career choices, for example, how can finance-major college students know what specialties to choose in the future during their freshmen year? How can they know if the subject is for them? If specialty-oriented career planning takes place in the early stages of their education, students can make better use of their time in that, the development of resources, licensing exams, work-study, and internships aimed at nurturing their professional capabilities (Peng, 2016).

One of the employability skills lacking among fresh graduates is the practical skill needed for school-to-work transition. Ogbuanya and Chukwuedo's study (2017) determined the longitudinal impact of career-training mentorship intervention on vocational electronic students' career-related behaviors and practical skills learning outcomes. They also found multiple mediation effects of career learning self-efficacy and work volition on the relationship between career-training mentorship and career-related behaviors (performance in practical skills). In Waddell et al.'s study (2015, p. 163), “Integrating a career planning and development program into the baccalaureate nursing curriculum, findings demonstrate that the intervention group reported higher perceived career resilience than the control group". The infusing model of career education program 
offered students the tools and resources to become confident, self-directed, and active in shaping their engagement in their academic program to help achieve their career goals. This similar findings as Huang, Peng, and Wang's study (2016, p. 259), "Investigating the effectiveness of infusing career education interventions into a learning support course for low-achieving business college students", the data revealed that there were statistically significant primary effects for the infusing career education intervention in terms of their perceptions of the career indecision and the study-improvement of the study strategy. Also, the positive correlations were found between grade-point average (GPA) and both learning motivation and time management.

After the expansion of higher education in Taiwan, technical college graduates are still no better off than general college graduates in applying what they learned. The problem of the "mismatch between education and occupations" that arises during the transition from college/university to work also expanded. Addressing this mismatch requires closing the gap that connects "institutions taught" and "student learned" with the employment market of the future, thus helping to achieve the educational goal of nurturing professional talent that can then apply what they have learned. The "mismatch between education and work" refers to the phenomenon where fresh graduates cannot apply their recently acquired knowledge and skills at the workplace. The analysis and report published by Weng, Kang, and Chang (2011) indicated that 55\% of young employees in 2010 believed that they could apply what they learned in school at work; while the rest of the employees maintained a reserved attitude about the relationship between what they learned and the jobs they currently have. The report also mentioned that,

from the perspective of applying what was learned, only $9 \%$ of technical college graduates believe that they are applying what they learned, a number which is lower than the $16 \%$ of people who graduated from general colleges, and even lower than the $13 \%$ of junior college graduates. Such a result is very different from the expectations of the general public, and shows that the current curriculum design and the instruction content of technical colleges are in need of re-examination.

\section{Audio-Visual Teaching Methods Turn a Career Planning Course Into an E-Learning System}

Teaching is an art and learning is an active process. In the 21 st century, teaching and learning are in the age of information. Using audio-visual teaching interventions is important to the learning process (Cakir, 2006). Al Mamun (2014) found that the use of audio-visual aids assists both the teacher and the learner in teaching and learning language skills. This study guided media teaching on effective is of audio-visual aids in language learning and gave suggestions that are given to the teacher on planning, preparing, conducting, and evaluating each educational sequence. Audio-visual teaching methods can be seen as a core with progression in concept development from direct, purposeful learning experience. Zhang, Zhou, Briggs, and Nunamaker's experimental study (2006) found that the value of video for learning effectiveness was contingent upon the provision of interactivity. Students in the e-learning environment that provided interactive video achieved significantly better learning performance and a higher level of learner satisfaction than those in other settings. Moreover, Bello and Goni's (2016) a survey study found that there is a significant relationship between students' academic performance and audio-visual instructional materials.

Spurk, Barthauer, and Heinemann's (2015) study sought to foster subjective career success by improving networking behavior, career planning, and career optimism. This study revealed an increase in career planning 
and career optimism within the networking plus career coaching intervention group was indirectly positively related to changes in subjective career success. The study found that the networking group training alone and in combination with the career coaching showed no effectiveness in fostering networking behavior. The similar finding as Peng, Y. H. Lin, and C. J. Lin's (2017) that compared with the traditional one-way lecture model, the most effective learners' satisfaction model is the model of including specialty-oriented lectures by finance alumni and assignments requiring the interviewing of upperclassmen, in addition to studying career counseling theory and specialty-topic content sharing. Taber and Blankemeyer (2015) indicated that future work self-predicted career planning and that career concern had an additive effect. Future work self also predicted proactive skill development and proactive career networking. And they suggest that future work self and career adaptability play an influential role in the engagement of proactive career behavior.

Nota, Santilli, and Soresi's study (2016), "A life-design-based online career intervention for early adolescents" found that using contemporary digital technology offers possibilities for better engaging youth in constructing their future careers and suggested that the life-design-based online career intervention increased students' narratives of future aspirations. What can research in applied psychology offer the growth of educational technology and instructional media? Spencer (2017) reminded that, for much of its history, educational technology has concerned with justifying and verifying the basic assumption that the processes and products of technology can improve instructional effectiveness and it both advocates and describes the forging of new links between the two disciplines. Therefore, as the above findings, it is now time for career planning to integrate career planning of audio-visual contents into the e-learning teaching plan (Peng \& Chu, 2018).

\section{Research Goals/Objects}

A good teaching plan and well-rounded teaching enthusiasm must accompany the specialty-oriented career planning course in higher learning institutions to achieve the goals of the curriculum and reap the expected benefits. The higher education departments that implement the curriculum of a specialty-oriented career-planning course must be able to make feasible and applicable arrangements within the combined planning and implementation of instruction content, including a range of teaching objectives, teacher specifications, schedule arrangements, and teaching procedures, to realize the teaching objectives of this program. The competent authority sets the parameters and indicators for students' learning satisfaction of the course, according to the objectives of the project, to examine the implementation effectiveness and results of the overall project.

Since 2014, the Taipei Youth Salon has collaborated with National Taipei University of Business (NTUB) on many projects relevant to this "specialty-oriented career planning" topic. There were two collaborative projects with NTUB on the Specialty-oriented career planning courses, and a Specialty-Oriented Career Group Counseling project with NTUB in the first half of 2017 (Peng, 2015, 2016; Peng et al., 2016; Shih, Peng, \& Fei, 2017). There are a lot of good memories for all participants in the process, and students experienced many positive impacts. In 2018, the cooperation project would bring us to the completion of a teaching manual for specialty-oriented courses with a series of "TYS Career Soft Power" video and supplementary audio files, to promote the practicality and feasibility of the "specialty-oriented career planning course" in higher education. Many creative activities designed in the past three collaborative projects are compiled with more elaborative improvements to form this teaching manual. 


\section{Description of the Research Program}

With its restructuring in 2014, NTUB set its development vision on becoming the best business college in Taiwan, with the core educational goal of cultivating professional business talent. So far, of the seven departments in NTUB, only the Finance Department offers a career planning course, which it started in 1996, and is the first department to offer a freshmen specialty-oriented "finance career planning" course, since the 2014 NTUB restructuring (Peng, 2015).

The goal of the Finance Department of NTUB is to cultivate first-rate finance professional talent. The goal of the financial career planning course is: (1) to help students to explore themselves, to be aware of the potential, and to cultivate independent thinking and creativity; (2) to help students to understand the various career paths and workplaces in the financial industry, to clarify future career goals, to cultivate soft power for the workplace, and to become experts in the financial field; (3) to help students to cultivate the right values, form good ethics, and gain internal motivation; and (4) to help students to enhance positive personal characteristics, and thus, be welcomed by the workplace: easy to get along with, respectful, responsible, fair, trustworthy, caring, and civically responsible. To become a leader in the workplace, one needs to learn the good characteristics of being led (Lin, 2016).

Having a professional specialty is the only way to survive in today's job market; every professional field is looking for its fervent disciples. The goal of the specialty-oriented career planning courses is to inspire students' independent thinking and creativity to find their specialty development direction and to establish career core beliefs and core values. The course can also inspire students' enthusiasm for self-career development, the strong motivation for studying, and the attitude toward living an earnest life. The instruction programs for specialty-oriented career planning courses or specialty-oriented group career counseling included thought-provocative lectures, career evaluation interactive activities, case discussions, career role models, creativity sharing and career development story-telling, etc.

\section{Method}

Teaching plan design and pilot program objectives are as following: The compilation of a practical teaching manual with supplementary audio and video files for specialty-oriented career planning courses. Design eighteen teaching plans based on career-related theories, and then compile various practical specialty-oriented career planning activities as the curriculum content. The production of the teaching plans and audio-visual files designed from students' perspectives, with fewer theories and easy to read, understand, and apply content.

The differences between courses offered in a general education scenario and the courses offered by specific departments of education are general education courses offered to students of all majors. Thus, the focuses are on the improvement of general career development abilities. While, departmental courses may choose to focus on in-depth exploration and characteristic details of each department or college. Therefore, career exploration topics may focus on future employment, academic development, or school/employment transition, as well as in-depth discussions on curriculum maps, or on the connection of learning and application.

\section{Program Focus and Strategy Scope}

Today's career counselors for higher education in Taiwan need to focus on the "specialty-oriented career counseling" for all the various departments to provide an adequate supply of professional talent to the job 
market. Students must continuously explore career options while they are in middle school and high school to better understand their career/study choices and to determine the direction of their studies. Once, they are at the college level, students have chosen a profession, so they need to focus on course planning and career planning for the benefit of their education and professional development.

The emphasis of specialty-oriented career counseling is "You may not do well at everything, but everyone is good at something", and its core is that all college graduates can apply what they have learned. The design goal of this course is to raise the level of understanding, for college freshmen, about required and elective courses of their majors (interdisciplinary and dual major) for their next four years; their future career choices in accordance with their own chosen profession; and to know whether they are suitable for studying the chosen subject. Thus, first-year college students can develop and realize their professional ambitions, while increasing their learning motivation and learning satisfaction. When entering their future workplace, they will continue learning for a lifetime, while improving job satisfaction, and treating their chosen professionals as "business careers" and "life careers". We hope that every college department will actively promote the "specialty-oriented career planning courses" to improve college students' "specialty employment rate", thereby enhancing the national competency in professional talent development (Lin \& Peng, 2015; Peng, Y. Lin, \& C. Lin, 2017).

The course content of the "specialty-oriented career planning courses" includes: understanding self, discovering potentials and career interests, clarifying work values, developing a positive outlook and career beliefs/career self-efficacy, enhancing time management, and planning for work-study/internship, actively participating in social communities and cultivating interpersonal communication skills. To help students understand the development trends of each professional field in actual practice, we invite alumni to return to their alma mater, or contact successful individuals in the industries relevant to each school of study, and arrange lectures or presentations, so that their professional development experience and hard-working spirits may be passed on. More importantly, is the building of strong contacts through these activities, and hopefully, a mentor system may establish between university/college students and alumni. As mentioned above, the teaching-plan contents focus on creative career planning activities.

\section{Course Objectives Tasks and Strategies}

Institutions of higher learning play an important role in promoting career development, thus, they should pay particular attention to the integration of higher education and workplace applications. In a career development process, if one can enter the professional arena smoothly and take a major role, one's life shall be as bright as a rainbow. The two major focuses of career development for youths still in colleges are academic development and future employment preparation. While understanding of self and good living adjustment are both pertinent to their academic development and employment readiness. If college students have properly planned their career development process, it will be easier for them to achieve the goal of self-development. Due to its internal nature, self-development can easily constitute a force for self-advance, driving strong learning motivation and a positive learning attitude.

Career planning in higher education must differentiate from career planning in high schools. College career planning courses should be freshmen electives in every department, to emphasize the importance of specialty-oriented career planning. The goals of specialty-oriented career planning are: (1) inspire students' independent thinking and creativity to find their specialty development direction and to establish career core 
beliefs and core values; and (2) inspire students' enthusiasm for self-career development, the motivation for studying, and the attitude for living an earnest life. As a result, a variety of learned knowledge can be integrated, thus achieving the ultimate goal of developing a sound professional talent. Career counseling should implement as an integral part of students' academic life. The curriculum for career planning in higher education may be designed around the basis of career theory, and then supplemented with specialty-oriented career planning related topics (Peng, 2015).

The career planning topics for high school and college may be divided in Table 1.

Table 1

The Career Planning Topics for High School and College

\begin{tabular}{|c|c|c|}
\hline $\begin{array}{l}\text { Nine major categories for high school career } \\
\text { planning }\end{array}$ & Lesson & Specialty-oriented career planning for colleges \\
\hline Preparation & 1 & The importance of grit \\
\hline $\begin{array}{l}\text { Topic 1: Growth process and career } \\
\text { development }\end{array}$ & 2 & Topic 1: The importance of career planning and career theory \\
\hline Topic 2: The exploration of personal traits & 3 & Topic 2: The importance of specialty-oriented career planning \\
\hline Topic 3: Life role and life style & 4 & Topic 3: Recognize your personality and multiple intelligences \\
\hline $\begin{array}{l}\text { Topic 4: Educational development and learning } \\
\text { groups, academic programs }\end{array}$ & 5 & Topic 4: Recognize your interests and advantages \\
\hline $\begin{array}{l}\text { Topic 5: High/Vocational school level career } \\
\text { paths and career options }\end{array}$ & 6 & Topic 5: The importance of career beliefs/positive beliefs \\
\hline $\begin{array}{l}\text { Topic 6: Professional life and social } \\
\text { requirements }\end{array}$ & 7 & Topic 6: Career values/fight for your dreams \\
\hline \begin{tabular}{|l} 
Topic 7: Career information and career \\
assessment
\end{tabular} & 8 & Topic 7: Time management \\
\hline Topic 8: Strategic styles and techniques & 9 & Topic 8: Reading methods/test methods \\
\hline Topic 9: Career action and practice & 10 & Topic 9: Decision strategy for career choices/career flow \\
\hline \multirow{9}{*}{ Career planning relevant topics } & & Relevant topic specialty-orientated folder-career action plan \\
\hline & 11 & Learning process planning-interviews: finding an academic mentor \\
\hline & 12 & Career narrative interviews-career interviews: finding a career mentor \\
\hline & 13 & Emotional injury and career planning \\
\hline & 14 & $\begin{array}{l}\text { The similarities and differences in the career development of men } \\
\text { and women }\end{array}$ \\
\hline & 15 & Listening to internal calls/spirituality, beliefs, and career planning \\
\hline & 16 & Planning for professional license tests \\
\hline & 17 & Spiritual map \\
\hline & 18 & There is no accidental fortune \\
\hline
\end{tabular}

\section{Overall Course Structure}

The specialty-oriented career planning course in higher education is structured with ten specialty-oriented career planning core topics and supplemented with eight careers planning relevant topics. Details as following: Teaching plans for College Level Specialty-oriented Career Planning Course (According to the freshmen or senior students' career counseling requirements, topics may be different).

Information on all 18-weeks of lesson topics can find in "TYS Career Soft Power" video on YouTube. The specialty-oriented career planning course in higher education is structured with ten specialty-oriented career planning core topics and supplemented with eight career planning relevant topics. 
Table 2

\begin{tabular}{|c|c|}
\hline Week & Topic/Teaching plans for college level "specialty-oriented career planning course" \\
\hline 1 & Introductory course/the importance of grit/grit scale \\
\hline 2 & Topic 1: Career planning and career planning theory \\
\hline 3 & Topic 2: The importance of specialty-oriented career planning \\
\hline 4 & Topic 3: Recognize your personality and multiple intelligences \\
\hline 5 & Topic 4: Career beliefs/positive beliefs/career myths \\
\hline 6 & Topic 5: Recognize your interests and advantages/irreplaceable workplace soft power \\
\hline 7 & Topic 6: Career value/fight for your dreams/job search skills \\
\hline 8 & Topic 7: Time management \\
\hline 9 & Topic 8: Study management/test methods \\
\hline \multirow[t]{2}{*}{10} & Topic 9: Decision strategy for career choices/career flow \\
\hline & $\begin{array}{l}\text { Relevant topics: Alumni talks "specialty development trends and workplace morality—workplace ethics and } \\
\text { hidden rules sharing" }\end{array}$ \\
\hline 11 & Career decision strategy (personal folder) \\
\hline 12 & Learning process planning-interviews: finding an academic mentor \\
\hline 13 & Career narrative interviews-career interviews: finding a career mentor \\
\hline 14 & Emotional injury and career planning; maintaining joy and be positive \\
\hline 15 & $\begin{array}{l}\text { The similarities and differences in the career development of men and women-a talk about career planning } \\
\text { for men and women }\end{array}$ \\
\hline 16 & Listening to internal calls/spirituality, beliefs, and career planning \\
\hline 17 & Planning for professional license tests (each department's license plan) \\
\hline 18 & $\begin{array}{l}\text { Spiritual map//there is no accidental fortune } \\
\text { Group presentations (interviewing their academic mentors or career mentors) }\end{array}$ \\
\hline
\end{tabular}

\section{Instructor's Responsibilities and Qualifications}

The teaching plan design of specialty-oriented courses is based on the one-syllabus-various-content principles and is intended to practice with actual examples. Instructors of various topics play significant roles in the course. The instructor of the "specialty-oriented career planning course" does not play an on-the-spot impromptu role; instead, the instructor must reference and follow the 18-week topic flow and the associated relevant topics to develop teaching content. Also, the instructor must sufficiently understand the goals of the entire course design and the expected teaching results. Thus, it may serve as an educational reference for each instructor to create one's teaching materials, and a basis for implementing each topic, or exercise actual cases, while encouraging students to comment and discuss.

Since the implementation of this program depends on the positive outcome of the interactive learning, the instructor's basic guiding principle cannot rely on one-way lecturing. Instead, the instructor must be able to recognize students' backgrounds and provide timely and appropriated encouragement for students to express their opinions and state their experiences, in addition to guiding the entire class to participate in a group discussion. An instructor is not only an interpreter of a course topic, but also a "show host" in the implementation process, to steer smooth progress of the "specialty-oriented career planning course" of their department.

\section{Responsibilities of the Implementing Department ${ }^{1}$}

To ensure the integrity of the original teaching methods in this pilot program, and to ensure implemented

${ }^{1}$ Colleges' and Universities' Employment Course Program assisted by The Ministry of Labor (2018). 
efficacy of the observable 18-week teaching plan for specialty-oriented career planning courses, it is appropriate planning, and execution responsibilities divided into pre-class, in-class, and after-class phases to set standards for evaluation. Before executing the topic combination of each unit, instructors of the implementing department must assume the responsibility of having a "consensus on the content of the said teaching plan". That is, an "Instructors Consensus Meeting" must be convened before implementing the topic of each unit. There are two main consensus issues: One is to communicate and coordinate teaching content and the lesson preparation of each unit before-class and its creative implementation plan; and the other one is for all instructors to perform and participate in the "video files playback and post-viewing activities" to ensure consistent planning and coordinated implementation process of each topic.

In the process of teaching each unit, the instructor must fulfill the responsibility of "process management"; that is, the instructor must improve their "quality teaching service" and participate in the "interaction between teacher/students". After the implementation of each topic completed, the instructor is responsible for implementing the follow-up discussion on "Improvement and Refinement of the Program". That is, the instructor must conduct the necessary "Performance Review" after completing each implementation. Also, the inadequacies and insufficiencies found in these reviews, after the first-year implementation of the program, must be rectified and improved during the implementation of the second year, so that this program's intended teaching goals may achieve as expected. Major responsibilities of the department give course instruction, when implementing the pilot program of this curriculum:

1. Implementing "one-syllabus-various-content" is the basic principle of planning the teaching content of this program. It has been proven through experience by many organizations and classes, those students are more satisfied when subjects are taught by complying with the said principle;

2. The method and timing of each teaching plan's drills are crucial to the implementation of the specialty-oriented career planning course which requires instructors' focused attention.

The key to successful teaching plans in this program relies on the activity designs in the teaching plan being specific for each actual drill, and that it must follow the principle of "inspiring students' learning motivation and enthusiasm" to enhance the effectiveness of the teaching.

\section{Expected Results}

The "TYS Career Soft Power" audio-visual YouTube files may be helpful for infusing career planning major points into any professional courses. Now, with the help of various institutional adjustment measures, we hope to mitigate the mismatch between education and work, and further assist young people in smoothly completing the transition from higher education to work. A good teaching plan and well-rounded teaching enthusiasm must accompany the specialty-oriented career planning course in higher learning institutions to achieve the goals of the curriculum and reap the expected benefits. The university/college department that implements the curriculum of a specialty-oriented career-planning course must be able to make feasible and applicable arrangements within the combined planning and implementation of instruction content including a range of teaching objectives, teacher specifications, schedule arrangements, and teaching procedures to realize the teaching objectives of this program. The competent authority sets the parameters and indicators for students' learning satisfaction of the course, according to the objectives of the project, to examine the implementation effectiveness and results of the overall project. Mid-term assignment assessment: A review of course content application, and a personal, academic career interview, or professional career interview assignment, with the 
inclusion of a personal folder being an extra-curriculum assignment (self-study). Final performance assessment includes presenting consolidated group mid-term reports in PowerPoint or video format: (1) academic career mentors - alumni interview; and (2) professional career mentors - experienced professional of the desired field (assignment for college senior).

College career planning courses should be part of the first-year student's elective course curriculum in each department to emphasize the importance of specialty-oriented career planning, thus improving future professional employability, professional competitiveness and the professional employment rate for college students. It is expected that these research results might serve as a reference for improving the curriculum planning for "specialty-oriented career planning classes and group counseling for any department" in higher education. Through the establishment of a specialty-oriented career planning course/group design, there will be a concrete and feasible vision for the promotion of "specialty-oriented career counseling". This set of courses can be used for flipped classroom curriculum or integrated into general education courses and professional courses.

\section{The Production of Teaching Plan and an Example of a Teaching Plan}

Eighteen weeks of specialty-oriented career planning teaching plan: for instructors' reference only, there are nine main topics and nine relevant topics. It is noted that a sample teaching plan referred to the audio-video pilot program of this teaching plan and 18 weeks of teaching plans collated into a teaching manual. Information on all 18-weeks of lesson topics can check in "TYS Career Soft Power" video on YouTube.

Table 3

A Sample Teaching Plan for College Level Specialty-Oriented Career Planning Course

\begin{tabular}{|c|c|c|c|c|}
\hline Course title & \multicolumn{4}{|l|}{ Specialty-oriented career planning course } \\
\hline Topic & \multicolumn{4}{|l|}{ Grit } \\
\hline The designer of the teaching plan & \multicolumn{4}{|l|}{ The author } \\
\hline \multicolumn{5}{|l|}{ Instructor } \\
\hline Teaching strategy & \multicolumn{4}{|l|}{ Inspire learning motivation } \\
\hline Method & \multicolumn{4}{|l|}{ Grit video on YouTube; video sharing } \\
\hline Resources/Equipment/Books & \multicolumn{4}{|l|}{ Grit } \\
\hline Assessment & \multicolumn{4}{|c|}{ Print personal course schedule/list personal learning and living goals } \\
\hline Total class time & \multicolumn{4}{|l|}{ Two hours } \\
\hline Teaching objective/Expected results & \multicolumn{4}{|c|}{$\begin{array}{l}\text { Introduction to the curriculum of this semester } \\
\text { Understanding grit } \\
\text { Setting goals and course arrangement } \\
\text { Persistent in achieving the semester goal set for oneself } \\
\text { Record personal attendance status } \\
\text { Personal folder for career planning for courses will complete in this semester }\end{array}$} \\
\hline Unit goal & Activities & Materials & Equipment & $\begin{array}{l}\text { Time } \\
\text { (minute) }\end{array}$ \\
\hline Understand "grit" & $\begin{array}{l}\text { The story of a little frog/grit scale } \\
\text { grit video watching } \\
\text { Teaching grit (PowerPoint) } \\
\text { https://tw.voicetube.com/videos/45429 }\end{array}$ & $\begin{array}{l}\text { Introduction to } \\
\text { books about } \\
\text { perseverance }\end{array}$ & $\begin{array}{l}\text { Computer/laptop } \\
\text { /smart phone }\end{array}$ & 50 minutes \\
\hline Setting goals and course arrangement & Print class schedule for the folder & \begin{tabular}{|l|}
$\begin{array}{l}\text { University/college } \\
\text { department } \\
\text { website }\end{array}$ \\
\end{tabular} & & 10 minutes \\
\hline
\end{tabular}


(Table 3 to be continued)

\begin{tabular}{|l|l|l|l|}
\hline $\begin{array}{l}\text { Persistence in achieving personal } \\
\text { goals }\end{array}$ & $\begin{array}{l}\text { List personal learning and living goals } \\
\text { Inspirational video appreciation }\end{array}$ & Activity list & 20 minutes \\
\hline Career planning personal folder & $\begin{array}{l}\text { Design a folder with personal featured } \\
\text { directory } \\
\text { Discussion: Learnings from } \\
\text { inspirational videos }\end{array}$ & Folder & 20 minutes \\
\hline Reference resources & $\begin{array}{l}\text { Dreamer Learning Website } \\
\text { QR Code } \\
\text { Scan }\end{array}$ & & \\
\hline Inspirational quote & The inspiration of the Story of the Little Frog-Just climb, no questions asked! \\
\hline
\end{tabular}

\section{Conclusion}

With the help of audio-visual YouTube files available for the career planning courses, this results of the research may serve as a reference for improving the application of "specialty-oriented career planning courses" or career group counseling for any department, thus achieving the goal of promoting the approach of "specialty-oriented career planning course" in higher education. Each department can emphasize the importance of specialty-oriented career planning, and thus improve future professional employability, professional competitiveness, and the professional employment rate for college students. The "TYS Career Soft Power" audio-visual YouTube files will be helpful for infusing career planning major points into any professional courses. The production of the teaching plans and audio-visual files designed from students' perspectives, with fewer theories and easy to read-understand-and-apply content.

The overall curriculum structure and course recommendation: This 18-week teaching plan program, with ten specialty-oriented career planning core topics and supplemented with eight career planning relevant topics to be implemented simultaneously, is an independent course, appropriate for general college, to be completed in one semester. The course design of the teaching materials and teaching plans mainly focused on the 18 weeks of video files and post-viewing discussion, including career planning related activities. This program implemented in two ways: A devoted "specialty-oriented career planning" as an elective, or integrate the curriculum into general education or professional education courses. Each department can emphasize the importance of specialty-oriented career planning, and thus improve future professional employability, professional competitiveness, and the professional employment rate for college students.

The audio-visual teaching plans for college-level specialty-oriented career planning courses are guiding students and practitioners through the planning process from a highly practical perspective. According to their interests, multiple intelligences, career beliefs, values, and other important self-awareness, students in higher education can have early specialty-oriented career planning, not wait till graduate and feel blankly do not know where to go. Using an original career planning framework, these teaching plans for each topic present a series of steps, tasks, and processes that help instructors develop effective teaching plans using a variety of approaches. This new design of the specialty-oriented career planning has been streamlined for efficiency, with information on the latest career education theories and trends in career planning. Hope that students in higher education will benefit from the 18 topics of the audio-visual lesson for college-level career planning courses. 


\section{References}

Al Mamun, M. (2014). Effectiveness of audio-visual aids in language teaching in tertiary level (Doctoral dissertation, BRAC University).

Bello, S., \& Goni, U. (2016). Relationship between audio-visual materials and environmental factors on students' academic performance in senior secondary schools in Borno State: Implications for counseling. Journal of Education and Practice, $7(24), 173-177$.

Cakir, I. (2006). The use of video as an audio-visual material in foreign language teaching classroom. Turkish Online Journal of Educational Technology-TOJET, 5(4), 67-72.

Huang, S., Peng, H., \& Wang, C. (2016). Investigating the effectiveness of infusing career education interventions into a learning support course for low-achieving business college students. Journal of Liberal Arts and Social, 12(4), 259-276.

Lin, Y. (2016). NTUB Finance Department Assessment Report (Unpublished).

Lin, Y., \& Peng, H. (2015). Youth Career Development Center Project Closure Report—“Career Counseling Education” Course Model Experimental Program (I) of the National Taipei University of Business and Taipei Youth Salon-Using the Finance Department of NTUB as an example (Unpublished).

Manpower Group. (2016). Manpower Group global employment talent shortfall survey. Retrieved November 1, 2016, from http://www.manpower.com.tw/

Nota, L., Santilli, S., \& Soresi, S. (2016). A life-design-based online career intervention for early adolescents: Description and initial analysis. The Career Development Quarterly, 64(1), 4-19.

Ogbuanya, T. C., \& Chukwuedo, S. O. (2017). Career-training mentorship intervention via the Dreyfus model: Implication for career behaviors and practical skills acquisition in vocational electronic technology. Journal of Vocational Behavior, 103, 88-105.

Peng, H. (2015). New news-An analysis of financial career planning courses, on the importance of "specialty-orientation career counseling" in Higher Education. NTUB E-Periodical, 2(1).

Peng, H. (2016). Action research on specialty-oriented career planning courses for financial college students-Using the Finance Department of NTUB as an example. The Journal of Open and E-learning, 6, 147-172.

Peng, H., \& Chu, Y. (2018). The audiovisual lesson plan design for college-level career planning courses. Paper presentation for Tokyo Japan the Annual Symposium on Management and Social Sciences (ASMSS) Conference, July 10-12, Hokkaido, Japan.

Peng, H., Lin, Y. H., \& Lin, C. J. (2017). Satisfaction evaluation of the effectiveness of the two models of specialty-oriented career planning course. International Journal of Psychological Studies, 9(3), 51.

Shih, Y., Peng, H., \& Fei, C. (2017). Taking flight "specialty-oriented career exploration": A satisfaction study on the group counseling for low-achievement college students-A NTUB and Taipei Youth Salon Program (A providence university research "Higher Education School Management Cultivation" academic seminar).

Spencer, K. (2017). The psychology of educational technology and instructional media. London: Routledge.

Spurk, D., Kauffeld, S., Barthauer, L., \& Heinemann, N. S. (2015). Fostering networking behavior, career planning and optimism, and subjective career success: An intervention study. Journal of Vocational Behavior, 87, 134-144.

Taber, B. J., \& Blankemeyer, M. (2015). Future work self and career adaptability in the prediction of proactive career behaviors. Journal of Vocational Behavior, 86, 20-27.

Waddell, J., Spalding, K., Canizares, G., Navarro, J., Connell, M., Jancar, S., \& Victor, C. (2015). Integrating a career planning and development program into the baccalaureate nursing curriculum: Part I. Impact on students' career resilience. International Journal of Nursing Education Scholarship, 12(1), 163-173.

Weng, K., \& Chang, F. (2011). The mismatch between education and work: School to work transition after higher education expansion. Review of Social Sciences, 5(1), 1-38.

Zhang, D., Zhou, L., Briggs, R. O., \& Nunamaker Jr, J. F. (2006). Instructional video in e-learning: Assessing the impact of interactive video on learning effectiveness. Information \& Management, 43(1), 15-27. 